\title{
PEMAHAMAN HAKIKAT SAINS OLEH SISWA DAN GURU SD DI KOTA SURAKARTA
}

\author{
Jumanto $^{1}$, Ari Widodo ${ }^{2}$ \\ Program Studi Pendidikan Dasar, Sekolah Pascasarjan, Universitas Pendidikan Indonesia \\ Email: antokarof@upi.edu ,widodo@upi.edu
}

\begin{abstract}
Abstrak
Penelitian ini bertujuan untuk mengidentifikasi tingkat pemahaman tentang hakikat sains (NOS) oleh siswa dan guru di kota Surakarta. Jenis penelitian yang dilakukan adalah deskriptif dengan metode survei. Sampel dari penelitian ini adalah 3 guru dan 20 siswa kelas 5 SD di daerah perbatasan Kota Surakarta, 3 guru dan 26 siswa kelas 5 SD di daerah pinggiran Kota Surakarta, serta 4 guru dan 36 siswa kelas 5 SD di daerah pusat Kota Surakarta. Instumen yang digunakan dalam penelitian berupa angket yang berisi 30 item pernyataan yang disusun oleh peneliti dengan berkonsultasi pada guru SD dan kepala sekolah serta dengan berdasarkan literatur yang terkait. Hasil penelitian menunjukkan bahwa tingkat pemahaman sains oleh siswa dan guru SD di Kota Surakarta keduanya pada kriteria cukup dengan skor 66,27 dan tidak ada perbedaan yang signifikan antara keduanya. Tetapi dengan uji korelasi pada $\alpha=0,05$ pada setiap aspek tingkat pemahaman sains oleh siswa dan guru SD di Kota Surakarta tidak ditemukan korelasi. Implikasi dari penelitian ini adalah pengetahuan tentang aspek NOS seharusnya mulai diperhatikan dan dikaji oleh semua civitas pendidikan sehingga siswa dan guru memahami NOS dengan sangat baik.
\end{abstract}

Kata kunci: hakikat sains, pemahaman siswa dan guru

\section{UNDERSTANDING THE NATURE OF SCIENCE BY STUDENTS AND ELEMENTARY SCHOOL TEACHERS IN THE CITY OF SURAKARTA}

\author{
Jumanto $^{1}$, Ari Widodo ${ }^{2}$ \\ Departement of Basic Education, Post Graduate, Universitas Pendidikan Indonesia \\ Email: antokarof@upi.edu,widodo@upi.edu
}

\begin{abstract}
This research is intended to know the level of understanding about the nature of science (NOS) by students and elementary school teachers in the city of Surakarta. The research type is descriptive with survey method. The sample of this research are 3 teachers and 20 students of grade 5 elementary school in the border area of Surakarta, 3 teachers and 26 students of grade 5 elementary school in suburban area of Surakarta, 4 teachers and 36 students of grade 5 elementary school in central area of Surakarta. The instrument used in this study is a questionnaire containing 30 items of statements prepared by researchers in consultation with primary school teachers and principals as well as on the basis of related literature. The results showed that the level of understanding of science by students and elementary school teachers in the city of Surakarta both on the criteria enough with a score of 66.27 and no significant difference between the two. But with correlation test at $\alpha=0,05$ on every aspect of science level understanding by students and elementary school teacher in Surakarta no correlation. The implication of this research is that knowledge about NOS aspect should start to be considered and studied by all civitas education so that students and teachers understand NOS very well
\end{abstract}

Keywords: The nature of science, student and teacher's understanding 


\section{PENDAHULUAN}

Istilah Nature Of Science (NOS) didefinisikan sebagai hakekat pengetahuan yang merupakan konsep yang kompleks melibatkan filosofi, sosiologi, dan historis suatu pengetahuan. Lederman et al., (2002) menegaskan bahwa NOS merupakan bagian yang berkenaan dengan pemahaman mengenai hakikat Sains ilmiah secara utuh. Pemahaman ini meliputi sifat empiris ilmu pengetahuan, sifat kreatif dan imaginatif, menanamkan sosial dan budaya, dan sifat tentatif. McComas (2008: 512) menyatakan bahwa adanya NOS dalam pendidikan bukan untuk mendoktrinasi, tetapi untuk menunjukkan alasan untuk menerima suatu keadaan tertentu. Lederman (2004: 303) menyatakan bahwa nature of science (NOS) merupakan epistemologi dari sains, sains sebagai cara untuk memperoleh pengetahuan, atau nilai-nilai dan keyakinankeyakinan yang melekat pada pengetahuan ilmiah atau pada pengembangan ilmu pengetahuan.

Pemahaman tentang hakikat sains ini sangat penting dalam pendidikan. Pemahaman tentang NOS dipandang sangat perlu untuk standar kelulusan dari pendidikan sains sebelum memasuki perkuliahan sehingga memiliki literasi sains (Khalick dkk, 2008: 835). Bahkan Mullis dan Jenkins (dalam Meichtry, 1993: 432) menyatakan bahwa pemahaman NOS yang baik dapat memberikan kemampuan intelektual yang dibutuhkan oleh seseorang untuk mengembangkan sains dan teknologi. Namun pemahaman terhadap hakikat sains sekarang kurang mendapat perhatikan dan keseriusan dari para civitas pendidikan. McComas (2015) Menyatakan "The nature of science (NOS) is an often neglected part of science teaching, yet it provides a vital background for students, detailing how science and scientists work and how scientific knowledge is created, validated, and influenced." Nature of Science (NOS) adalah bagian sains yang harus diajarkan oleh guru tetapi sering terbengkalai atau kurang mendapat perhatian. NOS dapat memberikan latar belakang yang penting bagi siswa tentang bagaimana sains dan ilmuwan bekerja dan bagaimana pengetahuan ilmiah tercipta, divalidasi, dan dipengaruhi.

Mengingat pentingnya pemahaman tentang hakikat sains tersebut, maka perlu ada sebuah penelitian yang mengungkap bagaimanakah tingkat pemahaman Sains utamanya di SD. Penelitian ini bermaksud untuk mengetahui tingkat pemahaman hakikat Sains oleh guru maupun siswa SD di daerah Kota Surakarta. Berawal dari penelitian ini, diharapkan natinya dapat dilanjutkan dengan peningkatan upaya pemahaman Sains secara masif.

Penelitian ini diawali dengan menelaah pendapat pendapat para ahli mengenai hakikat Sains atau nature of science (NOS). Menurut McComas (2008) secara umum NOS terbagi menjadi 3 bagian besar, yang 


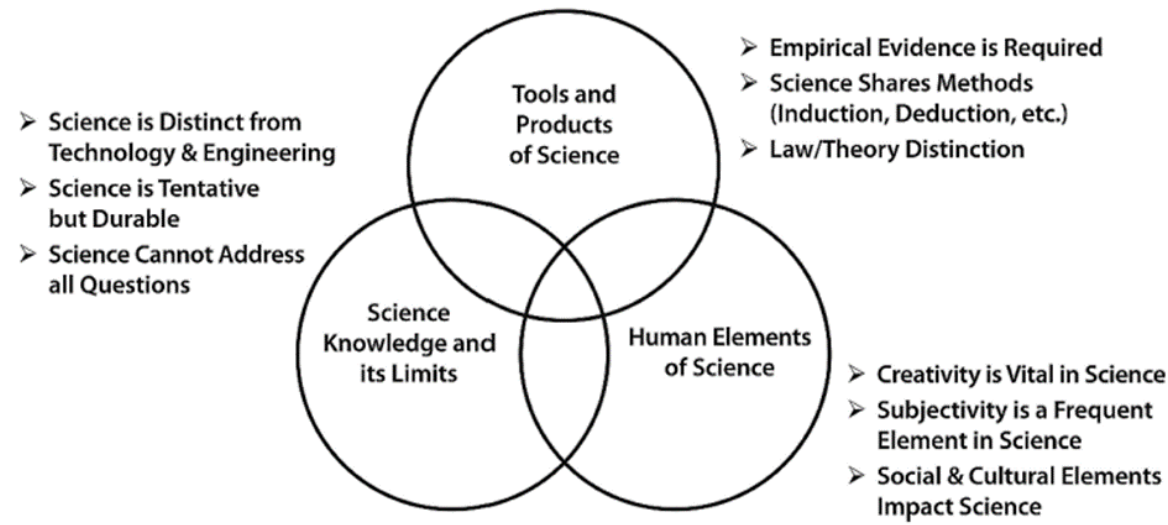

Gambar 1. The major elements of NOS appropriate for inclusion in science instruction, arranged in three related clusters (Mc Comas: 2008)

Selanjutnya Mc Comas membagi NOS tersebut menjadi beberapa aspek antara lain: Empirical evidence is required, Science shares methods (induction, deduction, etc), Law/theory distinction, Science is distinct from technology and engineering, Science is tentative but durable, Science cannot address all questions, Creativity is vital in science, Subjectivity is frequent element in science, Social and cultural elements impact science. Sedangkan menurut Next Generation
Science Standart (NGGS) NOS terdiri dari: Scientific knowledge is based on empirical evidence, Scientific knowledge is open to revision in light of new evidence, Science models, laws, mechanisms, and theories explain natural phenomena, Scientific investigation use a variety of methode. Selain itu juga banyak ahli yang membagi NOS menjadi beberapa aspek. Secara ringkas pendapat para ahli tersebut dapat dilihat pada tabel 1 di bawah ini:

\begin{tabular}{|c|c|c|c|c|c|c|c|c|c|c|c|}
\hline \multirow[b]{2}{*}{ No } & \multirow[b]{2}{*}{ Ahli } & \multicolumn{10}{|c|}{ Aspek Nature of Science } \\
\hline & & $\begin{array}{l}\text { Empi } \\
\text { ris } \\
\text { Base }\end{array}$ & $\begin{array}{l}\text { Tenta } \\
\text { tive }\end{array}$ & $\begin{array}{l}\text { Theories } \\
\text { and Law }\end{array}$ & $\begin{array}{c}\text { Socio, } \\
\text { Cultural } \\
\text { embedde } \\
\text { dness }\end{array}$ & $\begin{array}{l}\text { Creativ } \\
\text { ity }\end{array}$ & $\begin{array}{l}\text { scientific } \\
\text { method }\end{array}$ & $\begin{array}{l}\text { Subject } \\
\text { ive }\end{array}$ & $\begin{array}{l}\text { Cannot } \\
\text { Answer all } \\
\text { Questions }\end{array}$ & $\begin{array}{l}\text { Science and } \\
\text { technology } \\
\text { are not the } \\
\text { same }\end{array}$ & $\begin{array}{c}\text { distinction } \\
\text { between } \\
\text { observation \& } \\
\text { inference }\end{array}$ \\
\hline 1 & Mc Comas (2008) & $v$ & $v$ & $v$ & $v$ & $v$ & $v$ & $v$ & $v$ & $v$ & \\
\hline 2 & Alshamrani (2008) & $v$ & $v$ & $v$ & $v$ & $v$ & $v$ & $v$ & $v$ & $v$ & $v$ \\
\hline 3 & Lederman et al. 2002 & $v$ & $v$ & $v$ & $v$ & $v$ & $v$ & $v$ & & & \\
\hline 4 & $\begin{array}{l}\text { Jiang } \\
(2014)\end{array} \quad \& \quad$ McComas & $v$ & $v$ & & $v$ & $v$ & $v$ & $v$ & $v$ & & \\
\hline 5 & Southerland (2006) & $v$ & $v$ & $v$ & $v$ & $v$ & $v$ & $v$ & $v$ & & \\
\hline 6 & Hacieminoglu (2014) & $v$ & $v$ & $v$ & $v$ & $v$ & & $v$ & & & $v$ \\
\hline 7 & Bell (2008) & $v$ & $v$ & $v$ & & $v$ & $v$ & $v$ & & & $v$ \\
\hline 8 & NGGS (2013) & $v$ & $v$ & $v$ & & & $v$ & & & & \\
\hline 9 & $\begin{array}{l}\text { Abd-El-Khalick, bell, } \\
\text { and lederman (1998) }\end{array}$ & $v$ & $v$ & $v$ & $v$ & $v$ & & $v$ & & & $v$ \\
\hline 10 & Sufen Chen (2006) & $v$ & $v$ & $v$ & $v$ & $v$ & $v$ & $v$ & & & \\
\hline JUN & MLAH & 10 & 10 & 10 & 8 & 9 & 9 & 9 & 4 & 2 & 4 \\
\hline
\end{tabular}


Dari berbagai pendapat para ahli tersebut kemudian penulis menyimpulkan bahwa setidaknya nature of science memiliki 7 aspek yang harus ada. Ketujuh astek tersebut adalah: (1) Empiris Base (2) Tentative (3) Theories and Law (4) Socio Cultural embeddednes (5) Creativity (6) Scientific Method dan (7) Subjective. Selanjutnya dari ketujuh aspek tersebut dikaji pengertiannya secara mendalam dengan membandingkan pendapat para ahli. Berbekal pendapat para ahli selanjutnya penulis membuat sendiri definisi dari keujuh aspek tersebut. Selanjutnya tujuh aspek tersebut dijadikan dasar untuk penyusunan angket pemahaman sains oleh guru dan siswa Sekolah Dasar (SD).

Aspek pertama adalah Empiris Base. Secara sederhana Empiris Base maksudnya Pengetahuan ilmiah didasarkan pada data/bukti yang didapat dari observasi dengan panca indera dan/atau percobaan. Empiris Base memiliki dua indikator yaitu: (1)Pengetahuan ilmiah didasarkan pada data/bukti yang didapat dari observasi dengan panca indera (2) Pengetahuan ilmiah didasarkan pada data/bukti yang didapat dari percobaan.

Aspek kedua adalah Tentative. Pengetahuan bersifat Tentative maksudnya Pengetahuan ilmiah bukanlah sesuatu yang mutlak kebenarannya dan tanpa kesalahan.
Pengetahuan ilmiah dapat berubah (disempurnakan) dengan bukti pengamatan baru dan dengan reinterpretasi pengamatan yang ada. Aspek Tentative ini memiliki dua indikator yaitu: (1) Pengetahuan ilmiah bukanlah sesuatu yang mutlak kebenarannya dan tanpa kesalahan, dan (2) Pengetahuan ilmiah dapat berubah (disempurnakan) dengan bukti pengamatan baru dan dengan reinterpretasi pengamatan yang ada.

Aspek ketiga adalah Theories and Law. Pada aspek Theories and Law dapat diartikan sebagai pengetahuan ilmiah dapat berupa hukum atau berupa teori. Hukum menggambarkan hubungan, pengamatan atau persepsi, fenomena di alam. Hukum biasanya disertai dengan rumus matematis. Teori adalah penjelasan yang disimpulkan untuk fenomena alam dan mekanisme hubungan antara fenomena alam. Aspek Theories and Law ini memiliki dua indikator yaitu: (1) Hukum menggambarkan hubungan, pengamatan atau persepsi, fenomena di alam. Hukum biasanya disertai dengan rumus matematis. (2) Teori adalah penjelasan yang disimpulkan untuk fenomena alam dan mekanisme hubungan antara fenomena alam 
Aspek ke empat adalah Socio Cultural embeddednes. Pada aspek Socio Cultural embeddednes ini maksudnya ilmu pengetahuan adalah hasil usaha manusia, oleh karena itu, proses mendapatkan pengetahuan ilmiah dipengaruhi oleh masyarakat dan budaya di mana ia dipraktekkan. Sistem Nilai dan budaya akan mempengaruhi apa dan bagaimana ilmu pengetahuan dilakukan, ditafsirkan, dan diterima. Aspek Socio Cultural embeddednes ini memiliki dua indikator yaitu: (1) Ilmu pengetahuan adalah hasil usaha manusia, oleh karena itu, proses mendapatkan pengetahuan ilmiah dipengaruhi oleh masyarakat dan budaya di mana ia dipraktekkan, dan (2) Sistem Nilai dan budaya akan mempengaruhi apa dan bagaimana pengetahuan ilmiah ini dipraktekkan, ditafsirkan, dan diterima.

Aspek ke lima adalah Creativity. Pada aspek Creativity ini maksudnya pengetahuan ilmiah tercipta dari imajinasi manusia, kreativitas dan penalaran logis. Dengan kreativitas ini Pengetahuan ilmiah akan terus berkembang. Penciptaan Pengetahuan ilmiah ini didasarkan pada perencanaan, pengamatan dan kesimpulan yang kreatif. Aspek Creativity ini memiliki tiga indikator yaitu: (1) Pengetahuan ilmiah tercipta dari imajinasi manusia, kreativitas dan penalaran logis, (2) Kreativitas menjadikan Pengetahuan ilmiah akan terus berkembang, dan (3) Penciptaan Pengetahuan ilmiah didasarkan pada perencanaan, pengamatan dan kesimpulan yang kreatif.

Aspek ke enam adalah Scientific Method. Pada aspek Scientific Method ini maksudnya Tidak ada sebuah metode ilmiah yang pasti dan berlaku universal. Untuk melakukan penelitian, para ilmuwan bebas untuk menggunakan metode apapun asalkan dapat dipertanggung jawabkan. Aspek Scientific Method ini memiliki dua indikator yaitu: (1) Tidak ada sebuah metode ilmiah yang pasti dan berlaku universal, dan (2) Untuk melakukan penelitian, para ilmuwan bebas untuk menggunakan metode apapun asalkan dapat dipertanggung jawabkan

Aspek ke tujuh adalah Subjective. Pada aspek Subjective ini maksudnya Subyektivitas pribadi tak dapat terhindarkan dalam ilmu pengetahuan. Beberapa aspek pribadi akan mempengaruhi. Seperti Nilai pribadi, kepercayaan, agenda diri, dan pengalaman sebelumnya akan mempengaruhi apa dan bagaimana 
seorang ilmuwan melakukan pekerjaannya. Aspek Subjective ini memiliki dua indikator yaitu: (1) Subyektivitas pribadi tak dapat terhindarkan dalam ilmu pengetahuan, dan (2) Nilai pribadi, kepercayaan, agenda diri, dan pengalaman sebelumnya akan mempengaruhi apa dan bagaimana seorang ilmuwan melakukan pekerjaannya

\section{METODE PENELITIAN}

Penelitian ini menggunakan rancangan penelitian deskriptif. Rancangan deskriptif ini digunakan untuk mendeskripsikan pemahaman Guru dan Siswa SD terhadap karakter hakikat sains. Populasi dari penelitian ini adalah guru dan Siwa SD di Kota Surakarta. Teknik sampling yang digunakan adalah teknik area probability sampling. Sampel dari penelitian ini adalah
3 guru 20 siswa kelas 5 SD di daerah perbatasan Kota Surakarta, 3 guru 26 siswa kelas 5 SD di daerah pinggiran Kota Surakarta, dan 4 guru 36 siswa kelas 5 SD di daerah pusat Kota Surakarta. Penelitian ini dilakukan dengan memberikan instrumen NOS berupa angket kepada sampel. Instumen yang digunakan dalam penelitian berisi 30 item pernyataan yang disusun oleh peneliti dengan berkonsultasi pada guru SD dan kepala sekolah serta dengan berdasarkan literatur yang terkait dengan NOS.

Analisis terhadap pernyataan dari angket pertama dilakukan dengan memanfaatkan persentase jawaban yang benar untuk setiap karakter dan selanjutnya dideskripsikan. Pendeskripsian dilakukan dengan membandingkan persentase hasil jawaban benar dengan kategori yang ada di dalam tabel 2 persentase kriteria pemahaman berikut ini.

Tabel 2. Persentase kriteria pemahaman Hakikat Sains

\begin{tabular}{lcc}
\hline No. & Persentase Jawaban Benar & Kriteria \\
\hline 1 & $84-100$ & Sangat Baik \\
2 & $68-83$ & Baik \\
3 & $52-67$ & Cikup \\
4 & $36-51$ & Buruk \\
5 & $<36$ & Sangat Buruk \\
\hline Analisis berikutnya adalah dengan & signifikan antara Pemahaman Hakikat Sains \\
membandingkan skor perolehan pemahaman & oleh siswa dari masing masing sekolah \\
hakikat sains oleh Guru dan Siswa SD di & dengan menggunakan one way Anova, (2) \\
kota surakarta berbantuan software SPSS & Untuk melihat apakah terdapat perbedaan \\
versi 21. Hal ini bertujuan untuk (1) Untuk & yang signifikan antara Pemahaman Hakikat \\
melihat apakah terdapat perbedaan yang & Sains oleh siswa pada setiap aspek NOS
\end{tabular}


dengan one way Anova, (3) Untuk mengetahui tingkat Pemahaman Hakikat Sains oleh siswa di Kota Surakarta secara umum, (4) Untuk melihat apakah terdapat perbedaan yang signifikan antara Pemahaman Hakikat Sains oleh guru pada dua tingkatan umur dengan uji-t, (5) Untuk melihat apakah terdapat perbedaan yang signifikan antara Pemahaman Hakikat Sains oleh guru berdasarkan jenis kelamin dengan uji-t, (6) Untuk melihat apakah terdapat perbedaan yang signifikan antara Pemahaman Hakikat Sains oleh guru per aspek dengan one way Anova (7) Untuk mengetahui tingkat Pemahaman Hakikat Sains oleh guru di Kota Surakarta secara umum, dan (8) Untuk membandingkan antara Pemahaman Hakikat Sains oleh Guru dan Siswa SD di kota surakarta menggunakan uji korelasi.

\section{HASIL DAN PEMBAHASAN}

Pengambilan data dilakukan dengan angket yang di isi secara langsung tanpa dibawa pulang. Sehingga diharapkan pernyataan yang diisikan dalam angket benar-benar merepresentasikan pemahaman hakikat sains oleh subjek penelitian tanpa bantuan orang lain dan tanpa melihat sumber buku maupun internet. Berikut ini tabel 3. memuat hasil angket yang diisi oleh siswa SD dari 3 daerah di Kota Surakarta.

Tabel 3. Tingkat Pemahaman Sains oleh Siswa SD di Kota Surakarta

\begin{tabular}{cccccccccccc}
\hline \multirow{2}{*}{$\begin{array}{c}\text { Subjek } \\
\text { (daerah } \\
\text { SD) }\end{array}$} & $\begin{array}{c}\text { Empiris } \\
\text { Base }\end{array}$ & $\begin{array}{c}\text { Tenta } \\
\text { tive }\end{array}$ & $\begin{array}{c}\text { Theories } \\
\text { and Law }\end{array}$ & $\begin{array}{c}\text { Socio, } \\
\text { Cultural } \\
\text { embedded } \\
\text { ness }\end{array}$ & Creativity & $\begin{array}{c}\text { Scientific } \\
\text { method }\end{array}$ & $\begin{array}{c}\text { Subjecti } \\
\text { ve }\end{array}$ & $\begin{array}{c}\text { Skor } \\
\text { Sklah }\end{array}$ & Nilai & Kriteria \\
\hline Perbatasan & 71,25 & 57,75 & 70,00 & 65,25 & 71,17 & 61,00 & 58,50 & $\mathbf{4 5 4 , 9 2}$ & 64,99 & Cukup \\
\hline Pinggiran & 63,65 & 61,54 & 66,73 & 67,88 & 67,82 & 63,27 & 62,88 & $\mathbf{4 5 3 , 7 8}$ & 64,83 & Cukup \\
\hline Pusat Kota & 66,25 & 57,50 & 66,53 & 64,72 & 69,17 & 60,14 & 60,28 & $\mathbf{4 4 4 , 5 8}$ & 63,51 & Cukup \\
\hline Jumlah & 201,15 & 176,79 & 203,26 & 197,86 & 208,15 & 184,41 & 181,66 & $\mathbf{1 3 5 3 , 2 8}$ & 64,44 & Cukup \\
\hline Nilai & 67,05 & 58,93 & 67,75 & 65,95 & 69,38 & 61,47 & 60,55 & $\mathbf{6 4 , 4 4}$ & & \\
\hline Kriteria & Cukup & Cukup & Cukup & Cukup & Cukup & Cukup & Cukup & Cukup & &
\end{tabular}

Pada tabel 3 di atas terlihat bahwa tingkat Pemahaman Hakikat Sains oleh siswa di Kota Surakarta secara umum mendapat skor nilai sebesar 64,44. Artinya dengan skor nilai tersebut Pemahaman Hakikat Sains oleh siswa di Kota Surakarta secara umum pada kriteria cukup. Dengan berbantukan Software SPSS versi 21 maka dilakukan uji untuk mengetahui apakah terdapat perbedaan yang signifikan antara Pemahaman Hakikat Sains oleh siswa dari masing masing sekolah/daerah. Dengan uji Anova satu jalur didapat hasil dalam tabel 4 berikut ini: 
Tabel 4. Hasil Uji One Way Anova tingkat Pemahaman Hakikat Sains oleh siswa di Kota Surakarta

Skor_Pemahaman

\begin{tabular}{|l|r|r|r|r|r|}
\hline & Sum of Squares & df & Mean Square & F & Sig. \\
\hline Between Groups & 35,669 & 2 & 17,834 &, 911 &, 406 \\
Within Groups & 1546,128 & 79 & 19,571 & & \\
Total & 1581,797 & 81 & & & \\
\hline
\end{tabular}

Berdasar tabel 4 di atas terlihat bahwa nilai signifikansi sebesar 0,406. Karena nilai signifikansi $=0,406$ lebih dari $\alpha=0,05$ maka H0 diterima, dan H1 ditolak. Artinya tidak terdapat perbedaan yang signifikan antara Pemahaman Hakikat Sains oleh siswa dari masing masing sekolah/daerah pada pengujian dengan $\alpha=0,05$. Baik siswa dari pusat kota, pingiran kota maupun perbatasan kota memiliki Pemahaman tentang Hakikat Sains yang sama yaitu pada kriteria cukup.

Selanjutnya untuk melihat apakah terdapat perbedaan yang signifikan antara Pemahaman Hakikat Sains oleh siswa pada setiap aspek NOS dilakukan dengan uji Anova satu jalur berbantukan software SPSS versi 21. Dari uji yang telah dilakukan didapatkan hasil pada tabel 5 dibawah ini

Tabel 5 hasil uji Pemahaman Hakikat Sains oleh siswa pada setiap aspek NOS

\begin{tabular}{|l|r|r|r|r|r|}
\hline Skor_Pemahaman & Sum of Squares & df & Mean Square & F & Sig. \\
\hline Between Groups & 296,481 & 6 & 49,414 & 9,345 &, 0001 \\
Within Groups & 74,024 & 14 & 5,287 & & \\
Total & 370,505 & 20 & & & \\
\hline
\end{tabular}

Berdasar tabel 5 di atas terlihat bahwa nilai signifikansi sebesar 0,0001. Karena nilai signifikansi $=0,0001$ kurang dari $\alpha=0,05$ maka $\mathrm{H}_{0}$ ditolak, dan $\mathrm{H}_{1}$ diterima. Artinya terdapat perbedaan yang signifikan antara Pemahaman Hakikat Sains oleh siswa pada salah satu atau lebih aspek NOS, pada pengujian dengan $\alpha=0,05$. Perolehan skor nilai tertinggi dari hasil angket yaitu pada aspek creativity sebesar 69,39 sedangkan paling rendah yaitu pada aspek tentative sebesar 58,93.
Berdasarkan angket yang telah diisi oleh guru, diketahui bahawa secara umum Pemahaman Hakikat Sains oleh guru di kota Surakarta memiliki skor rata-rata sebesar 67,60. Dengan skor ini artinya guru memiliki Pemahaman Hakikat Sains pada kriteria cukup. Berikutnya untuk melihat apakah terdapat perbedaan yang signifikan antara Pemahaman Hakikat Sains oleh guru berdasarkan jenis kelaminnya dilakukan dengan uji-t berbantukan software SPSS 
versi 21, didapatkan hasil pada tabel 6

dibawah ini

Tabel 6. Independent Samples Test Pemahaman Hakikat Sains oleh guru berdasarkan jenis kelamin

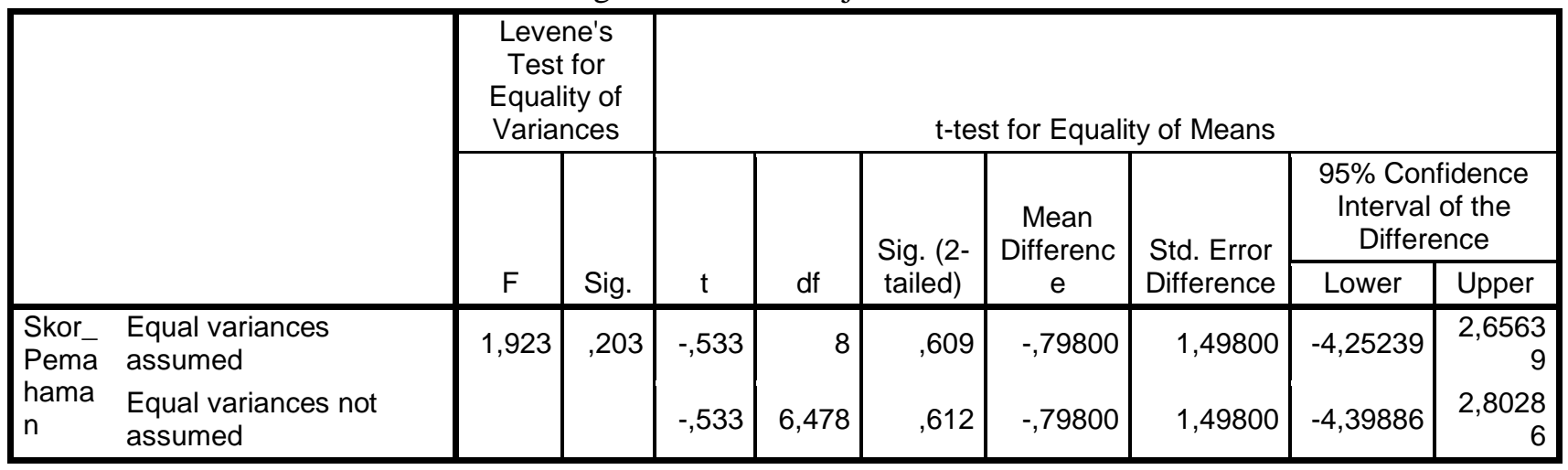

Berdasar tabel 6 di atas terlihat bahwa nilai signifikansi sebesar 0,203 . Karena nilai signifikansi $=0,203$ lebih dari $\alpha=0,05$ maka $\mathrm{H}_{0}$ diterima, dan $\mathrm{H}_{1}$ ditolak. Artinya tidak terdapat perbedaan yang signifikan antara Pemahaman Hakikat Sains oleh guru berdasarkan jenis kelaminnya pada pengujian dengan $\alpha=0,05$. Baik guru pria maupun wanita memiliki Pemahaman tentang Hakikat Sains yang relatif sama.
Pengujian berikutnya adalah untuk melihat apakah terdapat perbedaan yang signifikan antara Pemahaman Hakikat Sains oleh guru berdasarkan jenjang umurnya, yaitu guru yang berumur dibawah 40 tahun dan diatas 40 tahun. Pengujian dilakukan dengan uji-t berbantukan software SPSS versi 21. Dari uji yang telah dilakukan didapatkan hasil pada tabel 7

Tabel 7. Independent Samples Test Pemahaman Hakikat Sains oleh guru berdasarkan jenjang umurnya

\begin{tabular}{|c|c|c|c|c|c|c|c|c|c|}
\hline & \multicolumn{2}{|c|}{$\begin{array}{l}\text { Levene's Test } \\
\text { for Equality of } \\
\text { Variances }\end{array}$} & \multicolumn{7}{|c|}{ t-test for Equality of Means } \\
\hline & \multirow[b]{2}{*}{$\mathrm{F}$} & \multirow[b]{2}{*}{ Sig. } & \multirow[b]{2}{*}{$\mathrm{t}$} & \multirow[b]{2}{*}{ df } & \multirow{2}{*}{$\begin{array}{l}\text { Sig. (2- } \\
\text { tailed) }\end{array}$} & \multirow{2}{*}{$\begin{array}{c}\text { Mean } \\
\text { Differenc } \\
\mathrm{e}\end{array}$} & \multirow{2}{*}{$\begin{array}{l}\text { Std. Error } \\
\text { Difference }\end{array}$} & \multicolumn{2}{|c|}{$\begin{array}{l}95 \% \text { Confidence } \\
\text { Interval of the } \\
\text { Difference }\end{array}$} \\
\hline & & & & & & & & Lower & Upper \\
\hline $\begin{array}{ll}\text { Skor_- } & \text { Equal variances assumed } \\
\text { Pema } & \text { Equal variances not } \\
\text { haman } & \text { assumed }\end{array}$ & ,301 &, 598 & $\begin{array}{l}1,129 \\
1,129\end{array}$ & $\begin{array}{r}8 \\
7,868\end{array}$ & $\begin{array}{l}, 292 \\
, 292\end{array}$ & $\begin{array}{l}1,59800 \\
1,59800\end{array}$ & $\begin{array}{l}1,41577 \\
1,41577\end{array}$ & $\begin{array}{l}-1,66677 \\
-1,67630\end{array}$ & $\begin{array}{l}4,86277 \\
4,87230\end{array}$ \\
\hline
\end{tabular}

Berdasar tabel 7 di atas terlihat bahwa nilai signifikansi sebesar 0,598. Karena nilai signifikansi $=0,598$ lebih dari $\alpha=0,05$ maka
$\mathrm{H}_{0}$ diterima, dan $\mathrm{H}_{1}$ ditolak. Artinya tidak terdapat perbedaan yang signifikan antara Pemahaman Hakikat Sains oleh guru 
jenjang umurnya pada pengujian dengan $\alpha$ $=0,05$. Baik guru yang berumur dibawah 40 tahun dan diatas 40 tahun memiliki Pemahaman tentang Hakikat Sains yang relatif sama. Selanjutnya untuk melihat apakah terdapat perbedaan yang signifikan antara Pemahaman Hakikat Sains oleh guru pada setiap aspek NOS dilakukan dengan uji Anova satu jalur berbantukan software SPSS versi 21. Dari uji yang telah dilakukan didapatkan hasil pada tabel 8 dibawah ini

Tabel 8 hasil uji Pemahaman Hakikat Sains oleh guru pada setiap aspek NOS

Skor Pemahaman

\begin{tabular}{|l|r|r|r|r|r|}
\hline & Sum of Squares & df & Mean Square & F & Sig. \\
\hline Between Groups & 661,867 & 6 & 110,311 & 1,126 &, 379 \\
Within Groups & 2253,333 & 23 & 97,971 & & \\
Total & 2915,200 & 29 & & & \\
\hline
\end{tabular}

Berdasar tabel 5 di atas terlihat bahwa nilai signifikansi sebesar 0,379 . Karena nilai signifikansi $=0,379$ lebih dari $\alpha=0,05$ maka $\mathrm{H}_{0}$ diterima, dan $\mathrm{H}_{1}$ ditolak. Artinya tidak terdapat perbedaan yang signifikan antara Pemahaman Hakikat Sains oleh guru guru pada setiap aspek NOS, pada $\alpha=0,05$.

Pemahaman tentang Hakikat Sains oleh guru disetiap aspek relatif sama.

Dari hasil angket yang diisi oleh siswa dan guru SD di kota Surakarta dapat di ringkas menjadi satu pada tabel 9 berikut ini.

Tabel 9. Tingkat Pemahaman Sains oleh Siswa dan Guru SD di Kota Surakarta

\begin{tabular}{|c|c|c|c|c|c|c|c|c|c|c|}
\hline \multirow{2}{*}{$\begin{array}{c}\text { Subjek } \\
\text { (daerah } \\
\text { SD) }\end{array}$} & \multicolumn{7}{|c|}{ Aspek NOS } & \multirow[b]{2}{*}{$\begin{array}{l}\text { Jumlah } \\
\text { Skor }\end{array}$} & \multirow[b]{2}{*}{ Nilai } & \multirow[b]{2}{*}{ Kriteria } \\
\hline & $\begin{array}{c}\text { Empiris } \\
\text { Base }\end{array}$ & $\begin{array}{l}\text { Tenta } \\
\text { tive }\end{array}$ & $\begin{array}{l}\text { Theories } \\
\text { and Law }\end{array}$ & $\begin{array}{c}\text { Socio, } \\
\text { Cultural } \\
\text { embedded } \\
\text { ness }\end{array}$ & Creativity & $\begin{array}{l}\text { scientific } \\
\text { method }\end{array}$ & $\begin{array}{l}\text { Subjecti } \\
\text { ve }\end{array}$ & & & \\
\hline Siswa & 67,05 & 58,93 & 67,75 & 65,95 & 69,38 & 61,47 & 60,55 & 451,09 & 64,44 & Cukup \\
\hline Guru & 69,00 & 75,50 & 65,50 & 68,50 & 60,67 & 72,00 & 65,50 & 476,67 & 68,10 & Cukup \\
\hline Jumlah & 136,05 & 134,43 & 133,25 & 134,45 & 130,05 & 133,47 & 126,05 & 927,76 & 66,27 & Cukup \\
\hline Nilai & 68,03 & 67,21 & 66,63 & 67,23 & 65,03 & 66,73 & 63,03 & 66,27 & & \\
\hline Kriteria & Cukup & Cukup & Cukup & Cukup & Cukup & Cukup & Cukup & Cukup & & \\
\hline $\begin{array}{l}\text { Pada tab } \\
\text { Pemahan } \\
\text { guru SD } \\
\text { secara u } \\
66,27 \text {. D } \\
\text { tingkat } \\
\text { siswa da }\end{array}$ & $\begin{array}{l}9 \text { di ats } \\
\text { Hakik } \\
\text { ecara u } \\
\text { im men } \\
\text { man ske } \\
\text { mahama } \\
\text { guru SI }\end{array}$ & $\begin{array}{l}\text { terlih } \\
\text { t Sains } \\
\text { num di } \\
\text { apat st } \\
\text { nilai } \\
\text { Hak }\end{array}$ & $\begin{array}{l}\text { t bahwa } \\
\text { oleh sis } \\
\text { Kota } \mathrm{Su} \\
\text { or nilai } \\
\text { tersebut } \\
\text { at Sain } \\
\text { umum o }\end{array}$ & $\begin{array}{l}\text { tingkat } \\
\text { wa dan } \\
\text { Irakarta } \\
\text { sebesar } \\
\text { artinya } \\
\text { s oleh } \\
\text { li Kota }\end{array}$ & \multicolumn{6}{|c|}{$\begin{array}{l}\text { Surakarta secara umum pada kriteria cukup. } \\
\text { Skor tertinggi pemahaman hakikat sains oleh } \\
\text { siswa pada aspek creativity sebesar } 69,38 \\
\text { sedangkan Skor tertinggi pemahaman } \\
\text { hakikat sains oleh guru pada aspek tentative } \\
\text { yaitu sebesar } 75,50 \text {. Untuk skor terendah } \\
\text { pemahaman hakikat sains oleh siswa pada }\end{array}$} \\
\hline
\end{tabular}


aspek tentative sebesar 58,93 sedangkan Skor terendah pemahaman hakikat sains oleh guru pada aspek creativity yaitu sebesar 60,67. Temuan yang sangat menarik tentunya melihat keterbalikan antara skor tertinggi dan skor terendah siswa dan guru SD di Kota Surakarta.
Dengan temuan yang menarik seperti tersebut di atas, maka penulis melakukan uji korelasi antara skor tingkat pemahaman sains oleh siswa dan guru SD di Kota Surakarta. Hasil uji korelasi terlihat pada tabel 10 di bawah ini.

Tabel 10. Korelasi tingkat pemahaman sains oleh siswa dan guru SD

\begin{tabular}{|c|c|c|c|}
\hline & & subjek & $\begin{array}{c}\text { Skor_Pemaham } \\
\text { an }\end{array}$ \\
\hline \multirow[t]{3}{*}{ subjek } & Pearson Correlation & 1 &,- 405 \\
\hline & Sig. (2-tailed) & & ,151 \\
\hline & $\mathrm{N}$ & 14 & 14 \\
\hline \multirow[t]{3}{*}{ Skor_Pemahaman } & Pearson Correlation &,- 405 & 1 \\
\hline & Sig. (2-tailed) & ,151 & \\
\hline & $\mathrm{N}$ & 14 & 14 \\
\hline
\end{tabular}

Berdasar tabel 10 di atas terlihat bahwa nilai signifikansi sebesar 0,151. Karena nilai signifikansi $=0,151$ lebih dari $\alpha=0,05$ maka $\mathrm{H}_{0}$ diterima, dan $\mathrm{H}_{1}$ ditolak. Artinya tidak terdapat korelasi yang signifikan antara Pemahaman Hakikat Sains oleh siswa dan guru pada setiap aspek NOS, pada pengujian dengan $\alpha=0,05$.

Hasil penelitian ini kurang sesuai dengan hasil penelitian yang dilakukan oleh Tursinawati (2016) yang meneliti pemahaman hakekat sains oleh siswa SD di kota Banda Aceh Sesuai. Dalam penelitian Tursinawati tersebut menunjukkan bahwa kemampuan dasar siswa dalam penguasaan konsep hakikat sains adalah $40 \%$ pada kategori tidak baik (buruk), dan 60\% pada kategori cukup. Jika dibandingkan secara sederhana maka dapat dikatakan bahwa pemahaman tentang hakikat sains oleh siswa
SD di kota Surakarta lebih tinggi dari pada di kota Banda Aceh. Tetapi belum diketahui lebih lanjut faktor apakah yang menyebabkan adanya perbedaan pemahaman sains oleh siswa SD di dua daerah tersebut.

\section{KESIMPULAN DAN SARAN}

Berdasarkan hasil pengujian data diketahui bahwa tingkat pemahaman sains siswa dan guru SD di Kota Surakarta keduanya pada kriteria cukup akan tetapi pada setiap aspeknya tidak ditemukan korelasi. Artinya tidak terdapat hubungan yang selaras antara bahwa tingkat pemahaman sains siswa dan guru SD di Kota Surakarta. Hal ini terlihat dari keterbalikan nilai skor tertinggi dan terendah pada aspek creativity dan tentative oleh siswa dan guru SD. Dari hasil wawancara pada saat pengambilan data, diketahui 
bahwa guru masih merasa asing dengan istilah Nature Of Science (NOS).

Mengingat bahwa pemahaman tentang hakikat sains ini sangat penting, makas sebaiknya hal ini harus diperhatikan oleh semua civitas pendidikan. Perlu ada upaya untuk meningkatkan pemahaman hakikat sains ini oleh semua pihak yang terkait pendidikan di Surakarta. Gru harus mengkaji tentang hakikat sains, dosen dan peneliti perlu melakukan penelitian pengabdian, dan perlu mempublikasi penelitan yang terkait dengan pemahaman sains ini.

\section{DAFTAR PUSTAKA}

Alshamrani, S. M. (2008). Context, accuracy and level of inclusion of nature of science concepts incurrent high school physics textbooks. Ph.D. dissertation, University of Arkansas, Fayetteville, AR.

Bell, R. L. (2008). Best Practices in Science Education Teaching the Nature of Science : Three Critical Questions. Cengage.

Chen, S. (2006). Development of an Instrument to Assess Views on Nature of Science and Attitudes. https://doi.org/10.1002/sce.20147

Hacieminoglu, E. (2014). In-service Teachers Perceptions regarding their Practices related to Integrating Nature of Science: Case Study. Procedia - Social and Behavioral Sciences, 116(1988), 1268-1273. https://doi.org/10.1016/j.sbspro.2014.01.38 1

Jiang \& Mccomas, W. F. (2014). Analysis of Nature of Science Included in Recent Popular Writing Using Text Mining Techniques, (September). https://doi.org/10.1007/s11191-014-9703-0

Lederman, N. G., Abd-el-khalick, F., Bell, R. L., Hall, R., \& Street, E. (2002). Views of Nature of Science Questionnaire: Toward Valid and Meaningful Assessment of Learners ' Conceptions of Nature of Science, 39(6), 497-521. https://doi.org/10.1002/tea.10034
Lederman, N.G., and J.S. Lederman. (2004). "Revising instruction to teach nature of science". The Science Teacher. Vol. 71 (9), hlm. 36-39.

Khalick, Abd-El, Fouad, Lederman,N.G., Bell, Randy.L. 1998. The Nature of Science and Instructional Practice: Making the Unnatural Natural.Science Education, 82: 417-436. https://doi.org/10.1002/(SICI)1098237X(199807)82:4<417::AIDSCE1>3.0.CO;2-E

Khalick, Abd-El, Fouad, Dogan, Nihal. 2008. Turkish Grade 10 Students' and Science Teachers' Conceptions of Nature of Science: A National Study. Journal of Research in Science Teaching

Meichtry, Yvonne.J. 1993. The Impact of Science Curricula on Student Views About the Nature of Science. Journal of Research in Science Teaching, 30 (5): 429-443.

McComas, W.F. (2008). Proposals for core nature of science content in popular books on the history and philosophy of science: lessons for science education. In Y.J. Lee \& A.L. Tan (Eds.), Science Education at the Nexus of Theory and Practice. Rotterdam, The Netherlands: Sense

McComas, W. F. (2015). The Nature of Science \&amp; the Next Generation of Biology Education. The American Biology Teacher, 77(7), 485-491. https://doi.org/10.1525/abt.2015.77.7.2

Next Generation Science Standard. (2013). AHLMENDIX $H$ - Understanding the Scientific Enterprise: The Nature of Science in the Next Generation Science Standards. [Online] Tersedia di: http://www.nextgenscience. org/. Diakses 12 Desember 2013.

Southerland. 2006. Describing Teachers' Conceptual Ecologies for the Nature of Science. Published online 27 April 2006 in Wiley InterScience (www.interscience.wiley.com)

Chen, S. 2006. Development of an Instrument to Assess Views on Nature of Science and Attitudes Toward Teaching Science. Science Education, 90, 803-819

Tursinawati. 2016. Penguasaan Konsep Hakikat Sains dalam Pelaksanaan Percobaan pada Pembelajaran IPA di SDN Kota Banda Aceh. Jurnal Pesona Dasar Vol. 2, No. 4. Aceh: Universitas Syiah Kuala 